Situs Jurnal : $\underline{\text { http://ejurnal.stiepancasetia.ac.id/index.php/jieb }}$

Jilid 5 Nomor 1 Maret 2019

Hal 077 - 087

\title{
PENGARUH KUALITAS PELAYANAN TERHADAP KEPUASAN NASABAH TABUNGAN BANUA PT. BANK KALSEL CABANG PELAIHARI
}

\section{Artini Faurina* dan Khairunnisa}

Abstract: The purpose of this research is to know the significant influence of service quality variable consisting of tangible (physical appearance), reliability (trust), responsiveness (responsiveness), assurance (guarantee) and empathy (empathy) to user satisfaction simultaneously and partially at Faculty of Medicine Universitas Lambung Mangkurat Banjarbaru's Library. The type of research used in this research is descriptive research method with quantitative approach. The problem that the author thoroughly is a problem or symptoms that factual and also occur in the present (at the time of research done), then in this study the author uses descriptive method. Based on the result of the research, it can be concluded that: 1) Simultaneously or together the quality of service consisting of physical appearance, trust, responsiveness, assurance and empathy proved to significantly influence the satisfaction of library users of Faculty of Medicine Universitas Lambung Mangkurat Banjarbaru. 2) Partially or separately service quality variables that affect the satisfaction of library users Faculty of Medicine, University of Lambung Mangkurat Banjarbaru is the physical appearance and guarantee. 3) Quality Variables The most dominant service affects the satisfaction of library users of Faculty of Medicine Universitas Lambung Mangkurat Banjarbaru is a guarantee.

Keywords: service quality, user satisfaction, Faculty of Medicine Universitas Lambung Mangkurat Banjarbaru's Library

Abstrak: Tujuan dari penelitian ini adalah untuk mengetahui pengaruh signifikan secara simultan dan parsial variabel kualitas layanan yang terdiri dari berwujud (penampilan fisik), reliabilitas (kepercayaan), daya tanggap (responsiveness), assurance (jaminan) dan empati (empati) terhadap kepuasan pengguna di Perpustakaan Fakultas Kedokteran Universitas Lambung Mangkurat Banjarbaru. Jenis penelitian yang digunakan dalam penelitian ini adalah metode penelitian deskriptif dengan pendekatan kuantitatif. Masalah yang penulis tuntas adalah masalah atau gejala yang faktual dan juga terjadi pada masa sekarang (pada saat penelitian dilakukan), maka dalam penelitian ini penulis menggunakan metode deskriptif. Berdasarkan hasil penelitian, dapat disimpulkan bahwa: 1) Secara simultan atau bersama-sama kualitas layanan yang terdiri dari penampilan fisik, kepercayaan, daya tanggap, jaminan dan empati terbukti secara signifikan mempengaruhi kepuasan pengguna perpustakaan Fakultas Kedokteran Universitas Lambung. Mangkurat Banjarbaru. 2) Variabel kualitas layanan secara parsial atau terpisah yang mempengaruhi kepuasan pengguna perpustakaan Fakultas Kedokteran Universitas Lambung Mangkurat Banjarbaru adalah penampilan fisik dan jaminan. 3) Variabel Kualitas Layanan yang paling dominan mempengaruhi kepuasan pengguna perpustakaan Fakultas Kedokteran Universitas Lambung Mangkurat Banjarbaru adalah jaminan.

Kata kunci : kualitas pelayanan, kepuasan pengguna, Perpustakaan Fakultas Kedokteran Universitas Lambung Mangkurat 


\section{Latar Belakang}

Perkembangan perekonomian di negara Indonesia saat ini sangatlah kompleks, perkembangan ini dapat dilihat dari perkembangan yang ada.Dimulai dari tingkat regional sampai global.Pada saat ini pesatnya perkembangan ilmu pengetahuan maupun teknologi dapat berdampak pada perusahaan perbankkan, sehingga perusahaan harus selalu waspada dengan persaingan yang semakin kompleks.Bahkan para konsumen dalam menentukan pilihannya sangatlah selektif, karena semakin banyaknya produk maupun jasa yg ditawarkan oleh pelaku bisnis yang muncul di pasar.

Bank bagi masyarakat yang hidup di negara-negara maju merupakan kebutuhan dasar yang harus dipenuhi.bank merupakan mitra dalam memenuhi semua kebutuhan keuangan mereka sehari-hari. Bank dijadikan sebagai tempat untuk melakukan berbagai transaksi yang berhubungan dengan keuangan, seperti tempat mengamankan uang, melakukan investasi, pengiriman uang, melakuka/n pembayaran atau melakukan penagihan.

Bagi suatu negara bank dapat dikatakan sebagai darahnya perekonomian suatu negara.Oleh karena itu, peranan perbankan sangat mempengaruhi kegiatan ekonomi suatu negara. Dengan kata lain kemajuan suatu bank di suatu negara dapat pula dijadikan ukuran kemajuan negara yang bersangkutan. Semakin maju suatu negara, maka semakin besar peranan perbankan dalam mengendalikan negara tersebut.

Berbeda dengan di negara-negara berkembang seperti Indonesia, pemahaman tentang bank dinegeri ini belum utuh. Sebagian masyarakat hanya memahami bank sebatas tempat menyimpan dan meminjam uang, bahkan terkadang sebagian masyarakat sama sekali belum memahami fungsi bank seutuhnya, sehingga tidak heran jika pandangan mereka tentang bank sering diartikan secara keliru (Kasmir 2012:8).

Jika ditelusuri lewat sejarah sejak dulu sampai sekarang ini, peranan perbankan dalam memajukan perekonomian suatu negara sangatlah besar.Hampir semua sektor yang berhubungan dengan berbagai kegiatan keuangan selalu membutuhkan jasa bank. Oleh karena itu saat ini dan di masa yang akan datang setiap negara dan individu kita tidak akan lepas dari dunia perbankan, jika hendak menjalankan aktifitas keuangan, baik perorangan maupun lembaga.

Banyaknya persaingan membuat bank semakin kreatif dalam mencari ide-ide baru untuk menjadikan bank lebih baik dari para kompetitor, bank tidak dapat hanya mengandalkan dari kualitas produk, namun bank juga harus memberikan pelayanan yang dapat membuat konsumen puas, maka dari itu bank harus selalu memberikan pelayanan terbaiknya. Apabila bank dapat memberikan pelayanan yang terbaik secara berkala dan dapat memberikan sesuai dengan harapan yang diinginkan oleh konsumen (pelanggan) maka pelanggan akan merasa puas dengan kualitas yang diberikan oleh bank. Untuk mendapatkan kepuasan pelanggan secara utuh bukanlah hal yang sangat mudah, dikarenakan konsumen saat ini sangatlah selektif dan kritis dalam menentukan pilihan produk maupun jasa. Oleh sebab itu pihak bank haruslah dapat melihat apa yang diinginkan oleh para konsumen. Perusahaan perbankan yang menyediakan jasa harus dapat memberikan perhatian pada kualitas yang unggul.

Mengingat loyalitas pelanggan dapat dicapai jika pelanggan merasa sangat benar-benar puas dengan produk maupun jasa yang digunakan.Pemberian pelayanan terbaik hanya dapat diberikan jika perusahaan dapat menjaga dan meningkatkan kualitas jasa atau pelayanan yang diberikannya.Konsumen (nasabah) dapat menilai sebuah kualitas pelayanannya terhadap bank setelah konsumen menerima jasa atau pelayanan yang diberikan oleh bank tersebut.

Kepuasan nasabah merupakan sebuah perbandingan dari apa yang diharapkan dengan apa yang diterima nasabah. Apabila yang diterima oleh nasabah melebihi harapannya, maka 
nasabah tersebut dapat meraih kepuasan.Sebaliknya, apabila harapan nasabah lebih tinggi dari yang didapatkan, maka nasabah tersebut belum terpuaskan. Dalam hal ini bank harus mampu meningkatkan kepuasan tersebut sehingga nasabah tidak beralih kepada bank lain.Nasabah dapat menilai sebuah kualitas pelayanan melalui lima aspek penting yaitu aspek reliabilitas (realibility), daya tanggap (responsiveness), jaminan (assurance), empati (empathy) dan bukti fisik (tangibles). Kelima aspek ini dikenal dengan aspek kualitas pelayanan.

PT Bank Kalsel Cabang Pelaihari memberikan jasa danpelayananbank tersebut melaluitabungan,giro,deposito,pinjaman, investasi dan lain-lain.Bank Kalsel menawarkan produk dari perbankan salah satunya adalah Tabungan.Produk tabungan terdiri dari tiga jenis pertama adalah Simpeda dengan saldo minimal Rp 20.000 tabungan jenis ini memiliki nasabah paling banyak karena mampu menjangkau pada lapisan masyarakat bawah.

Produk tabungan kedua yaitu Tabunganku dengan saldo minimal Rp 50.000 dan menempatkan produk Tabunganku pada urutan kedua dalam hal jumlah nasabah.Produk yang tiga yaitu Tabungan Banua.Tabungan Banua sebagai salah satu produk andalan Bank Kalsel memberikan keistimewaan bagi nasabahnya yaitu salah satunya adalah bebas antrian, maksudnya nasabah pemegang Tabungan Banua tidak perlu antri di loket Bank.Keistimewaan yang diperoleh nasabah Tabungan Banua tentunya memiliki persyaratan yang harus dipenuhi nasabah salah satunya adalah saldo minimal dalam rekening tabungan Rp 2.500.000 yang memiliki perbedaan yang cukup signifikan dibandingkan dengan nasabah Tabungan biasa minimal saldo Rp 50.000, untuk suku Bunga nasabah Tabungan Banua mendapatkan Bunga sebesar 2\% untuk penyimpanan sampai denan Rp 50.000.000 dan Bunga 2.25\% untuk simpanan di atas Rp 50.000.000.

Pelayanan lebih atau keistimewaan yang di dapatkan oleh nasabah Tabungan seharusnya dapat meningkatkan jumlah nasabah Tabungan Banua.Kepuasan pelanggan diukur dengan seberapa besar harapan konsumen tentang produk dan pelayanan sesuai dengan kinerja produk dan pelayan yang aktual. Kepuasan akan mendorong konsumen akan membeli ulang produk, sebaliknya jika kecewa konsumen tidak mengulangi membeli produk (Sangadji, 2013:181). Berdasarkan data yang ada jumlah nasabah dan jumlah simpanan pada Tabungan Banua dari tahun 2014 sampai tahun 2017 tidak mengalami peningkatan yang signifikan hal ini dikarenakan jumlah saldo mengendap yang dianggap terlalu tinggi sehingga nasabah merasa kurang puas dengan ketentuan yang diterapkan oleh pihak PT Bank Kalsel Cabang Pelaihari, berikut data nasabah simpanan Tabungan Banua.

Tabel 1. Data Nasabah dan Simpanan Tabungan Banua Periode 2014-2017

\begin{tabular}{ccccr}
\hline \multirow{2}{*}{ Tahun } & \multicolumn{2}{c}{ Non Aktif } & \multicolumn{2}{c}{ Aktif } \\
\cline { 2 - 5 } & Jumlah Nasabah & Jumlah Simpanan & Jumlah Nasabah & Jumlah Simpanan \\
\hline 2017 & 45 & Rp 1.173.411.685 & 78 & Rp 6.823.266.061 \\
\hline 2016 & 45 & Rp 1.509.268.506 & 76 & Rp 11.509.032.888 \\
\hline 2015 & 45 & Rp 1.778.950.891 & 76 & Rp 6.418.849.993 \\
\hline 2014 & 45 & Rp 2.585.358.638 & 76 & Rp 9.240.514.035 \\
\hline
\end{tabular}

Berdasarkan pada data diatas dengan berjalannya waktu nasabah Tabungan Banua tidak mengalami peningkatan jumlah yang signifikan dan jumlah simpanan nasabah Tabungan Banua cenderung mengalami penurunan. Berdasarkan pada fenomena di atas peneliti tertarik untuk melakukan penelitian yang berjudul "Pengaruh Kualitas Pelayanan terhadap Kepuasan Nasabah Tabungan Banua PT Bank Kalsel Cabang Pelaihari”, 
Berdasarkan pada latar belakang yang telah dikemukakan, dapat disampaikan rumusan masalah dari penelitian ini, yaitu sebagai berikut:

1. Apakah variabel kualitas pelayanan yaitutampilan fisik, kepercayaan, daya tanggap, jaminandan empatisecara simultan berpengaruh signifikan terhadap kepuasan nasabah Tabungan Banua PT Bank Kalsel Cabang Pelaihari?

2. Apakah variabel kualitas pelayanan yaitu tampilan fisik, kepercayaan, daya tanggap, jaminandan empati secara parsial berpengaruh signifikan terhadap kepuasan nasabah Tabungan Banua PT Bank Kalsel Cabang Pelaihari?

3. Manakah variabel kualitas pelayanan yang terdiri dari tampilan fisik, kepercayaan, daya tanggap, jaminandan empati berpengaruh dominan terhadap kepuasan nasabah Tabungan Banua PT Bank Kalsel Cabang Pelaihari?

\section{Kajian Literatur}

Manajemen pemasaran berasal dari dua kata yaitu manajemen dan pemasaran.Menurut Kotler dan Amstrong dalam Oentoro (2012:13) pemasaran adalah analisis, perencanaan, implmentasi, dan pengendalian dari program-program yang dirancang untuk menciptakan, membangun, dan memelihara pertukaran yang menguntungkan dengan pembeli sasaran untuk mencapai tujuan perusahaan. Sedangkan manajemen adalah proses perencanaan (planning), pengorganisasian (organizing) penggerakan (actuating) dan pengawasan (controlling).

Menurut Dharmesta dalam Oentoro (2012:13) manajeman pemasaran merupakan salah satu kegiatan pokok yang dilakukan oleh perusahaan untuk mempertahankan kelangsungan perusahaannya, untuk berkembang, dan untuk mendapatkan laba. Sedangkan pendapat lain manajemen pemasaran dapat didefinisikan sebagai proses penganalisaan, perencanaan, pelaksanaan, dan pengawasan program-program yang bertujuan menimbulkan pertukaran dengan pasar yang dituju dengan maksud untuk mencapai tujuan perusahaan (Oentoro, 2012:13).

Dari uraian tersebut dapat disimpulkan bahwa manajemen pemasaran adalah sebagai kegiatan yang direncanakan, dan diorganisasikan yang meliputi pendistribusian barang, penetapan harga dan dilakukan pengawasan terhadap kebijakan-kebijakan yang telah dibuat. Nuryadin (2012:115) memberikan batasan mengenai bauran pemasaran, yaitu:

1. Produk

Merupakan bentuk penawaran organisasi jasa yang ditujukan untuk mencapai tujuan melalui pemuasan kebutuhan dan keinginan pelanggan. Produk disini bisa berupa apa saja (baik yang berwujud fisik maupun tidak) yang dapat ditawarkan kepada pelanggan potensial untuk memenuhi kebutuhan dan keinginan tertentu.

2. Harga

Bauran harga berkenaan dengan kebijaksanaan strategis dan taktis seperti tingkat harga, struktur diskon, syarat pembayaran dan tingkat diskriminasi harga diantara berbagai kelompok pelanggan.Harga menggambarkan besarnya rupiah yang harus dikeluarkan seorang konsumen untuk memeroleh satu buah produk dan hendaknya harga dapat terjangkau oleh konsumen.

3. Saluran Distribusi

Merupakan keputusan distribusi menyangkut kemudahan akses terhadap jasa bagi para pelanggan.Tempat dimana produk tersedia dalam sejumlah saluran distribusi dan outlet yang memungkinkan konsumen dapat dengan mudah memperoleh suatu produk. 


\section{Promosi}

Bauran promosi meliputi berbagai metode yaitu iklan, promosi penjualan, penjualan tatap muka dan hubungan masyarakat. Menggambarkan berbagai macam cara yang ditempuh perusahaan dalam rangka menjual produk ke konsumen.

Sunardi (2012:191) mengungkapkan bauran pemasaran terdiri dari empat komponen yaitu produk, harga, tempat, dan promosi.Keempat komponen dikenal dengan istilah "Four Ps" (product, pricing, place, promotion). Dan penjelasannya seperti berikut ini

1. Produk

Produk adalah langkah awal dari proses pemasaran. Suatu produk harus dibuat semenarik mungkin agar dapat mengikat konsumennya.Banyak hal yang harus dipertimbangkan dalam menciptakan produk, salah satu yang paling berpengaruh adalah teknologi. Seiring dengan kemajuan teknologi, keinginan seseorang akan suatu barang semakin beraneka macam. Ketika telah ada laptop misalnya, permintaan konsumen akan personal komputer menurun drastis.

2. Harga

Ada dua aspek yang harus diseimbangkan ketika perusahaan akan menetapkan harga produknya, yaitu harga perolehan atau cost dan kompetitor. Di satu sisi perusahaan harus memperhitungkan harga perolehan, yaitu harga beli produk, biaya angkut pembelian, dan biaya-biaya lain yang harus dikorbankan untuk membuat suatu produk siap jual. Disisi lain, perusahaan harus meyadari bahwa jika harga yang ditawarkan terlalu tinggi, maka besar kemungkinan perusahaan tersebut akan kalah saing dengan kompetitornya. Oleh karena itu, perusahaan harus menentukan harga yang menunjukan keseimbangan antara kedua aspek tersebut.

3. Tempat

Dalam bauran pemasaran, makna tempat lebih ditunjukan pada penyaluran produk kepada konsumen (proses distribusi). Perusahaan harus mencari cara terbaik untuk mendekatkan produknya kepada para konsumen di antaranya dengan mempertimbangkan kendaraan apa yang sesuai untuk mengantarkan produk kepada konsumen, apakah barang tersebut langsung di jual kepada konsumen atau melalui agen, pedagang besar, atau pedagang kecil, apakah perusahaan memerlukan gudang, dan bagaimana cara perusahaan untuk mengontrol sediaan produknya di masyarakat.

4. Promosi

Promosi adalah sebuah teknik untuk menyalurkan informasi mengenai produkproduk.Promosi sangat berpengaruh dalam memikat pembeli untuk membeli suatu produk.Media cetak, seperti Koran, mjalah, dan tabloud, dan media elektronik, seperti radio, televisi, dan internet banyak digunakan sebagai media promosi.

Pelayanan menurut Moenir (2014:27) adalah serangkaian kegiatan, karena itu bisa disebut juga dengan proses. Sebagai proses, pelayanan berlangsung secara rutin dan berkesinambungan. Meliputi seluruh kehidupan orang dalam masyarakat. Pelaksanaan pelayanan dapat diukur, oleh karena itu dapat ditetapkan standar baik dalam hal waktu yang diperlukan maupun hasilnya.Dengan adanya standar manajemen dapat merencanakan, melaksanakan, mengawasi dan mengevaluasi kegiatan pelayanan, agar supaya hasil akhir memuaskan pada pihak-pihak yang mendapatkan layanan.

Menurut Tjiptono (2014:59)Kualitas pelayanan adalah tingkat keunggulan yang diharapkan dan pengendalian atas tingkat keunggulan tersebut untuk memenuhi keinginan pelanggan. Apabila jasa atau pelayanan yang diterima atau dirasakan (perceived service) 
sesuai dengan yang diharapkan, maka kualitas jasa atau pelayanan dipersepsikan baik dan memuaskan. Jika jasa atau pelayanan yang diterima melampaui harapan pelanggan, maka kualitas jasa atau pelayanan dipersepsikan sebagai kualitas yang ideal. Sebaliknya jika jasa atau pelayanan yang diterima lebih rendah daripada yang diharapkan, maka kualitas jasa atau pelayanan dipersepsikan buruk.

\section{Metode Penelitian}

Penelitian dengan judul Pengaruh Kualitas Pelayanan terhadap Kepuasan Nasabah Tabungan Banua PT Bank Kalsel Cabang Pelaihari merupakan penelitian jenis korelasional. Penelitian korelasional adalah penelitian dengan cara mengumpulkan sejumlah data untuk melihat apakah ada suatu keterkaitan antara suatu variabel dengan variabel lain.

Menurut Sugiyono (2016:117) populasi adalah wilayah generalisasi yang terdiri atas obyek/subjek yang mempunyai kualitas dan karakteristik tertentu yang ditetapkan oleh peneliti untuk dipelajari dan kemudian ditarik kesimpulan.Populasi dalam penelitian ini adalah seluruhnasabah Tabungan Banua Bank Kalsel yang berjumlah 123 orang nasabah. Menurut Gunawan (2013:2) yang dimaksud sampel adalah sebagian atau wakil populasi yang diteliti atau secara lebih sederhana sampel penelitian adalah sebagian dari populasi yang diambil sebagai sumber data dan dapat mewakili seluruh populasi. Dalam penelitian ini peneliti menggunakan teknik pengambilan sampel purposive sampling, Menurut Sugiyono (2008:91) teknik purposive sampling adalah cara pengambilan sampel dengan pertimbangan tertentu, sampel yang digunakan dalam penelitian berjumlah 55 orang nasabah Tabungan Banua.

Jenis data yang digunakan dalam penelitian ini ada dua macam, yaitu data kuantitatif dan data kualitatif.

1. Data Kuantitatif

Menurut Sugiyono (2016:14) data kuantitatif merupakan data angka atau numerik. Adapun data kuantitatif dalam penelitian ini adalah: data pengolahan hasil penelitian yang digunakan untuk menghitung validitas dan reliabilitas kuisioner, serta menghitung regresi linier berganda.

2. Data Kualitatif

Menurut Sugiyono (2016:14) data kualitatif merupakan data non angka. Adapun data kualitatif dalam penelitian ini adalah: menjelaskan secara detail tentang kualitas pelayanan dan kepuasan nasabah Tabungan Banua Bank Kalsel Cabang Pelaihari.

Data dalam penelitian ada dua yaitu data primer dan data sekunder. Menurut Sugiyono (2016:39) data primer yaitu data yang langsung dikumpulkan oleh peneliti dari sumber utamanya, dan data sekunder biasanya telah tersusun dalam dokumen-dokumen.

1. Data Primer

Data primer didapatkan melalui observasi, wawancara, dan penyebaran kuisioner.

2. Data Sekunder

Data sekunder penelitian ini diperoleh dari bahan kepustakaan dan literatur serta data-data yang berasal dari lokasi penelitian.

Beberapa teknik yang digunakan peneliti dalam pengumpulan data penelitian ini adalah:

1. Field Research/Studi Lapangan

a. Wawancara

Wawancara adalah salah satu instrument yang digunakan untuk menggali data secara lisan, hal ini harus dilakukan secara mendalam agar mendapatkan data yang valid dan detail (Sujarweni, 2014:74). Wawancara dalam penelitian ini dilakukan dengan cara 
mengadakan tanya jawab kepada nasabah Tabungan Banua mengenai kualitas pelayanan dan kepuasan nasabah tersebut.

b. Angket

Menurut Sugiyono (2016:199) angket merupakan teknik pengumpulan data yang dilakukan dengan cara memberikan seperangkat pertanyaan atau pernyataan tertulis kepada responden untuk dijawab. Bentuk kuesioner bersifat tertutup maksudnya responden diberi alternartif dari setiap jawaban pada setiap pertanyaan. Seluruh variabel akan diukur menggunakan skala likert. Setiap alternatif jawaban diberi bobot seperti ditunjukkan pada Tabel 2.

Tabel 2. Skor dan Kode Alternatif Jawaban

\begin{tabular}{clcc}
\hline No & Pilihan Jawaban & Skor & Kode \\
\hline 1 & Sangat Setuju & 5 & SS \\
\hline 2 & Setuju & 4 & S \\
\hline 3 & Netral & 3 & N \\
\hline 4 & Tidak Setuju & 2 & TS \\
\hline 5 & Sangat Tidak Setuju & 1 & STS \\
\hline
\end{tabular}

Sumber: Sugiyono (2016:135)

c. Observasi

Observasi adalah pengamatan dan pencatatan secara sistematik terhadap gejala yang tampak pada objek penelitian (Sujarweni, 2014:75).Observasi dalam penelitian ini untuk mengetahui bagaimana kualitas pelayanan yang diberikan oleh pegawai Bank Kalsel serta bagaimana kepuasan nasabah Tabungan Banua.

d. Dokumentasi

Menurut Sukmadinata (2012:220) studi dokumenter merupakan suatu teknik pengumpulan data dengan menghimpun dan menganalisis dokumen-dokumen, baik dokumen tertulis, gambar maupun elektronik.Studi dokumenter dalam penelitian ini adalah meminta data mengenai hal-hal yang berkaitan dengan Bank Kalsel Cabang Pelaihari.

2. Library/Kepustakaan

Menurut Sujarweni (2014:57) kajian pustaka berisi teori-teori yang relevan dengan masalah penelitian, pada bagian ini dilakukan pengkajian mengenai konsep dan teori yang digunakan berdasarkan literatur yang tersedia, terutama dari artikel-artikel yang dipublikasikan dalam berbagai jurnal ilmiah.Kajian pustaka berfungsi membangun konsep atau teori yang menjadi dasar studi dalam penelitian.Adapun kajian pustaka yang digunakan dalam penelitian ini berasal dari buku-buku dan jurnal ilmiah yang berhubungan dengan materi penelitian.

\section{Hasil Penelitian dan Pembahasan}

Setelah dilakukan berbagai pengujian dan analisis, maka ditemukan hasil seperti ditunjukkan pada Tabel 3. Berdasarkan pada tabel 3 dapat dituliskan persamaan regresinya sebagai berikut:

$Y=-1.621+-0.093 X 1+0.503 X 2+0.338 X 3+0.148 X 4+-0.033 X 5$ 
Tabel 3. Hasil Estimasi Regresi Berganda

\begin{tabular}{|c|c|c|c|c|c|}
\hline $\begin{array}{l}\text { Variabel } \\
\text { Dependen }\end{array}$ & \multicolumn{2}{|c|}{ Variabel Independen } & $\mathrm{t}_{\text {hitung }}$ & Sig & Beta \\
\hline Kepuasan & \multicolumn{2}{|c|}{ 1. Tampilan fisik } & -1.967 & 0.055 & -0.150 \\
\hline Nasabah & \multicolumn{2}{|c|}{ 2. Kepercayaan } & 7.811 & 0.000 & 0.614 \\
\hline & \multicolumn{2}{|c|}{ 3. Daya tanggap } & 4.646 & 0.000 & 0.375 \\
\hline & \multicolumn{2}{|c|}{ 4. Jaminan } & 3.075 & 0.003 & 0.232 \\
\hline & \multicolumn{2}{|c|}{ 5. Empati } & -0.634 & 0.529 & -0.042 \\
\hline \multicolumn{2}{|l|}{ Constant } & $:-1.621$ & & & \\
\hline \multicolumn{2}{|c|}{ Adjusted R Square } & $: 0,787$ & & & \\
\hline \multicolumn{2}{|l|}{ F hitung } & $: 40.860$ & & & \\
\hline \multicolumn{2}{|c|}{$\mathrm{F}_{\text {tabel }} 5 \%$ pada $\mathrm{df}(55-6)$} & $: 2.01$ & & & \\
\hline \multicolumn{2}{|c|}{$\mathrm{T}_{\text {tabel }} 5 \%$ pada df $(55-6)$} & $: 2.30$ & & & \\
\hline
\end{tabular}

Persamaan regresi berganda tersebut dapat diuraikan sebagai berikut:

a: Nilai constanta sebesar -1.621 menunjukkan jika tidak ada variabel tampilan fisik, kepercayaan, daya tanggap, jaminan dan empati, maka kepuasan nasabah Tabungan Banua PT Bank Kalsel Cabang Pelaiharitetap sebesar -1.621.

$b_{1}$ : Koefisien regresi sebesar -0.093 untuk variabel tampilan fisik adalah elastisitas jumlah variabel kepuasan nasabah Tabungan Banua PT Bank Kalsel Cabang Pelaihari, mempunyai makna bahwa jika ditingkatkan satu kali pada variabel tampilan fisik maka kepuasan nasabah Tabungan Banua PT Bank Kalsel Cabang Pelaihariakan turun sebesar 0.093, sedangkan variabel lainnya tidak berubah.

$\mathrm{b}_{2}$ : Koefisien regresi sebesar 0.503 untuk variabel kepercayaan adalah elastisitas jumlah variabel kepuasan nasabah Tabungan Banua PT Bank Kalsel Cabang Pelaihari, mempunyai makna bahwa jika ditingkatkan satu kali pada variabel kepercayaan maka kepuasan nasabah Tabungan Banua PT Bank Kalsel Cabang Pelaihariakan naik sebesar 0.503, sedangkan variabel lainnya tidak berubah.

$\mathrm{b}_{3}$ : Koefisien regresi sebesar 0.338 untuk variabel daya tanggap adalah elastisitas jumlah variabel kepuasan nasabah Tabungan Banua PT Bank Kalsel Cabang Pelaihari, mempunyai makna bahwa jika ditingkatkan satu kali pada variabel daya tanggap maka kepuasan nasabah Tabungan Banua PT Bank Kalsel Cabang Pelaihariakan naik sebesar 0.338, sedangkan variabel lainnya tidak berubah.

b4: Koefisien regresi sebesar 0.148 untuk variabel jaminan adalah elastisitas jumlah variabel kepuasan nasabah Tabungan Banua PT Bank Kalsel Cabang Pelaihari, mempunyai makna bahwa jika ditingkatkan satu kali pada variabel jaminan maka kepuasan nasabah Tabungan Banua PT Bank Kalsel Cabang Pelaihariakan naik sebesar 0.148, sedangkan variabel lainnya tidak berubah.

$b_{5}$ : Koefisien regresi sebesar -0.033 untuk variabel empati adalah elastisitas jumlah variabel kepuasan nasabah Tabungan Banua PT Bank Kalsel Cabang Pelaihari, mempunyai makna bahwa jika ditingkatkan satu kali pada variabel empati maka kepuasan nasabah Tabungan Banua PT Bank Kalsel Cabang Pelaihariakan turun sebesar 0.033, sedangkan variabel lainnya tidak berubah. 
Uji t digunakan peneliti untuk mengetahui pengaruh masing-masing variabel independen secara terpisah/parsial terhadap variabel dependen, seperti ditunjukkan pada Tabel 4.

Tabel 4. Tabel Coefficients (Hasil perhitungan $t$ hitung)

\begin{tabular}{|c|c|c|c|c|c|c|c|c|}
\hline \multirow{2}{*}{\multicolumn{2}{|c|}{ Model }} & \multicolumn{2}{|c|}{$\begin{array}{c}\text { Unstandardized } \\
\text { Coefficients }\end{array}$} & \multirow{2}{*}{$\begin{array}{c}\text { Standardized } \\
\text { Coefficients } \\
\text { Beta }\end{array}$} & \multirow[t]{2}{*}{$\mathrm{T}$} & \multirow[t]{2}{*}{ Sig. } & \multicolumn{2}{|c|}{$\begin{array}{l}\text { Collinearity } \\
\text { Statistics }\end{array}$} \\
\hline & & $B$ & Std. Error & & & & Tolerance & VIF \\
\hline \multirow[t]{6}{*}{1} & (Constant) & -1.621 & 2.138 & & -.758 & .452 & & \\
\hline & Tampilan Fisik & -.093 & .047 & -.150 & -1.967 & .055 & .682 & 1.466 \\
\hline & Kepercayaan & .503 & .064 & .614 & 7.811 & .000 & .638 & 1.568 \\
\hline & Daya Tanggap & .338 & .073 & .375 & 4.646 & .000 & .606 & 1.649 \\
\hline & Jaminan & .148 & .048 & .232 & 3.075 & .003 & .696 & 1.436 \\
\hline & Empati & -.033 & .053 & -.042 & -.634 & .529 & .915 & 1.093 \\
\hline
\end{tabular}

a. Dependent Variable: Kepuasan Nasabah

Berdasarkan pengolahan data dengan SPSS versi 21.0 diketahui bahwa nilai t hitung untuk variabel tampilan fisik (X1) -1,967 lebih kecil dari nilai t tabel 2.01, dengan demikian tampilan fisik tidak berpengaruh secara signifikan terhadap kepuasan nasabah Tabungan Banua PT Bank Kalsel Cabang Pelaihari. Nilai t hitung untuk variabel kepercayaan (X2) 7.811 lebih besar dari nilai t tabel 2.01, dengan demikian kepercayaanberpengaruh secara signifikan terhadap kepuasan nasabah Tabungan Banua PT Bank Kalsel Cabang Pelaihari. Nilai t hitung untuk variabel daya tanggap (X3) 4.646 lebih besar dari nilai t tabel 2.01, dengan demikian daya tanggapberpengaruh secara signifikan terhadap kepuasan nasabah Tabungan Banua PT Bank Kalsel Cabang Pelaihari. Nilai thitung untuk variabel jaminan (X4) 3.075 lebih besar dari nilai t tabel 2.01, dengan demikian jaminanberpengaruh secara signifikan terhadap kepuasan nasabah Tabungan Banua PT Bank Kalsel Cabang Pelaihari. Nilai t hitung untuk variabel empaty (X5) -0.634 lebih kecil dari nilai t tabel 2.01, dengan demikian empatytidakberpengaruh secara signifikan terhadap kepuasan nasabah Tabungan Banua PT Bank Kalsel Cabang Pelaihari.

Uji $\mathrm{F}$ digunakan untuk mengetahui pengaruh variabel independen secara bersamasama/simultan terhadap variabel dependen, seperti ditunjukkan pada Tabel 5.

Tabel 5. Tabel ANOVA (Hasil perhitungan f hitung)

\begin{tabular}{llrrrrr}
\multicolumn{1}{l}{ Model } & & Sum of Squares & df & Mean Square & F & Sig. \\
\hline \multirow{2}{*}{1} & Regression & 169.376 & 5 & 33.875 & 40.860 & $.000^{\mathrm{b}}$ \\
\cline { 2 - 7 } & Residual & 40.624 & 49 & .829 & & \\
\cline { 2 - 7 } & Total & 210.000 & 54 & & &
\end{tabular}

a. Dependent Variable: Kepuasan Nasabah

b. Predictors: (Constant), Empati, Tampilan Fisik, Kepercayaan, Jaminan, Daya Tanggap

Berdasarkan pengolahan data dengan SPSS versi 21.0 diketahui bahwa nilai $\mathrm{F}$ hitung adalah 40.860 lebih besar dari $\mathrm{F}$ tabel yaitu sebesar 2.30, dengan demikian secara simultan tampilan fisik, kepercayaan, daya tanggap, jaminan, empati berpengaruh terhadap kepuasan nasabah Tabungan Banua PT Bank Kalsel Cabang Pelaihari.

Koefisien beta digunakan untuk mengetahui pengaruh variabel indenpen yang paling kuat pengaruhnya terhadap variabel dependen, berikut hasil perhitungannya:

1. Pengaruht ampilan fisik, kepercayaan, daya tanggap, jaminan, empati secara simultan terhadap kepuasan nasabah Tabungan Banua PT Bank Kalsel Cabang Pelaihari. Kepuasan 
nasabah Tabungan Banua PT Bank Kalsel Cabang Pelaihari yang diwakili oleh 5 butir pertanyaan berdasarkan pengolahan data dengan SPSS versi 21.0 diketahui bahwa nilai $\mathrm{f}$ hitung adalah 40.860 lebih besar dari nilai f tabel yaitu sebesar 2.30, dengan demikian tampilan fisik, kepercayaan, daya tanggap, jaminan, empatisecara bersama-sama/simultan berpengaruh secara signifikan terhadap kepuasan nasabah Tabungan Banua PT Bank Kalsel Cabang Pelaihari.

2. Pengaruh tampilan fisik, kepercayaan, daya tanggap, jaminan, empati secara parsial terhadap Kepuasan kepuasan nasabah Tabungan Banua PT Bank Kalsel Cabang Pelaihari.

a. Pengaruh tampilan fisik terhadap kepuasan nasabah Tabungan Banua PT Bank Kalsel Cabang Pelaihari.

Tampilan fisik yang diwakili oleh 5 butir pertanyaan berdasarkan pengolahan data dengan SPSS versi 21.0 diketahui bahwa nilai t hitung untuk variabel tampilan fisik (X1) -1.967 lebih kecil dari nilai t tabel 2.01, dengan demikian tampilan fisik tidak berpengaruh secara signifikan terhadap kepuasan nasabah Tabungan Banua PT Bank Kalsel Cabang Pelaihari.

b. Pengaruh kepercayaan terhadap kepuasan nasabah Tabungan Banua PT Bank Kalsel Cabang Pelaihari.

Kepercayaan yang diwakili oleh 5 butir pertanyaan berdasarkan pengolahan data dengan SPSS versi 21.0 diketahui bahwa nilai t hitung untuk variabel kepercayaan (X2) 7.811 lebih besar dari nilai t tabel 2.01, dengan demikian kepercayaan berpengaruh secara signifikan terhadap kepuasan nasabah Tabungan Banua PT Bank Kalsel Cabang Pelaihari.

c. Pengaruh daya tanggap terhadap kepuasan nasabah Tabungan Banua PT Bank Kalsel Cabang Pelaihari.

Daya tanggap yang diwakili oleh 5 butir pertanyaan berdasarkan pengolahan data dengan SPSS versi 21.0 diketahui bahwa nilai t hitung untuk variabel daya tanggap (X3) 4.646 lebih besar dari nilai t tabel 2.01, dengan demikian daya tanggapberpengaruh secara signifikan terhadap kepuasan nasabah Tabungan Banua PT Bank Kalsel Cabang Pelaihari.

d. Pengaruh jaminan terhadap kepuasan nasabah Tabungan Banua PT Bank Kalsel Cabang Pelaihari.

Jaminan yang diwakili oleh 5 butir pertanyaan berdasarkan pengolahan data dengan SPSS versi 21.0 diketahui bahwa nilai t hitung untuk variabel jaminan (X4) 3.075 lebih besar dari nilai t tabel 2.01, dengan demikian jaminanberpengaruh secara signifikan terhadap kepuasan nasabah Tabungan Banua PT Bank Kalsel Cabang Pelaihari.

e. Pengaruh empati terhadap kepuasan nasabah Tabungan Banua PT Bank Kalsel Cabang Pelaihari.

Empati yang diwakili oleh 5 butir pertanyaan berdasarkan pengolahan data dengan SPSS versi 21.0 diketahui bahwa nilai t hitung untuk variabel empati (X5) -0.634 lebih kecil dari nilai t tabel 2.01, dengan demikian empati berpengaruh secara signifikan terhadap kepuasan nasabah Tabungan Banua PT Bank Kalsel Cabang Pelaihari. 
Variabel bebas/independen dalam penelitian yaitu tampilan fisik, kepercayaan, daya tanggap, jaminan, empati, berdasarkan uji dominan hasil pengolahan data dengan SPSS versi 21.0 diketahui bahwa variabel kepercayaan (X2) 0.614 lebih dominan berpengaruh terhadap kepuasan nasabah Tabungan Banua PT Bank Kalsel Cabang Pelaihari.

\section{Kesimpulan} berikut:

Berdasarkan hasil pengolahan data penelitian, maka dapat dibuat kesimpulan sebagai

1. Secara simultan Kualitas Pelayanan yang diwakili oleh variabel tampilan fisik, kepercayaan, daya tanggap, jaminan, empati berpengaruh terhadap kepuasan nasabah Tabungan Banua PT Bank Kalsel Cabang Pelaihari

2. Secara parsial Kualitas Pelayanan yang terdiri dari variabel kepercayaan, daya tanggap dan jaminan berpengaruh signifikan terhadap kepuasan kepuasan nasabah Tabungan Banua PT Bank Kalsel Cabang Pelaihari, sedangkan kualitas pelayanan yang lain yaitu variabel tampilan fisik dan empatitidak berpengaruh secara parsial terhadap kepuasan nasabah Tabungan Banua PT Bank Kalsel Cabang Pelaihari.

3. Variabel Kualitas Pelayanan yang berpengaruh dominan terhadap kepuasan nasabah Tabungan Banua PT Bank Kalsel Cabang Pelaihari adalah variabel kepercayan.

Berdasarkan pada hasil kesimpulan dari penelitian ini, maka saran yang dapat diutarakakan adalah sebagai berikut:

1. Karena tidak seluruh variabel kualitas pelayanan berpengaruh signifikan terhadap kepuasan nasabah Tabungan Banua PT Bank Kalsel Cabang Pelaihari, maka disarankan agar ditingkatkan kualitas pelayanan kepada nasabah, terutama pada tampilan fisik dan empati.

2. Manajemen PT Bank Kalsel Cabang Pelaihari diharapkan agar memiliki strategi lain untuk meningkatkan kepuasan nasabah.

3. Dan bagi peneliti yang lain hendaknya meneliti faktor lain tentang kualitas pelayanan yang tidak diteliti dalam penelitian ini.

\section{DAFTAR PUSTAKA}

Moenir, H, A,S. 2014. Manajemen Pelayanan Umum Di Indonesia. Jakarta: Bumi Aksara

Nuryadin, Asli. 2012. Manajemen Perusahaan. Yogyakarta.LaksBang.

Oentoro, Deliyanti. 2012. Manajemen Pemasaran Modern. Yogyakarta.LaksBang.

Sugiyono. 2008. Metode Penelitian Administrasi. Bandung: Alfabet

Sugiyono. 2016. Metode Penelitian Pendidikan. Bandung. Alfabeta.

unardi. 2012. Bisnis Pengantar, Konsep, Strategi dan Kasus. Yogyakarta: Caps.

Sujarweni, 2014, Statistik Untuk Bisnis dan Ekonomi, Pustaka Baru, Yogyakarta

Sukmadinata, Syaodih, Nana. 2012. Metode Penelitian Pendidikan. Bandung: Remaja Rosdakarya.

Tri Hari Koestanto, 2014, Pengaruh Kualitas Pelayanan Terhadap Kepuasan Pelanggan Pada

Bank Jatim Cabang Klampis Surabaya

Tjiptono, Fandi. 2014. Strategi Pemasaran. Yogyakarta: Andi 